\title{
SERVICE QUALITY TERHADAP KEPUASAN MASYARAKAT MASS RAPID TRANSIT (MRT) DKI JAKARTA DI STASIUN LEBAK BULUS PADA MASA PANDEMIK COVID-19
}

\author{
Anggi Yuniarti, Toddy Aditya \\ Universitas Muhammadiyah Tangerang \\ yuniartianggi08@gmail.com, toddy_aditya@umt.ac.id
}

\begin{abstract}
MRT (Mass Rapid Transit) applies health protocols to prove the serve during pandemic. It is done to decrease the spread of COVID-19. Service quality is improved to the interests of the society that using the Jakarta MRT. MRT applies the health protocol named BANGKIT (Bersih, Aman, Nyaman, Go Green, Kolaborasi, Inovasi, and Tata Kelola). The research aims to know the satisfaction level towards user society satisfaction as the passenger of Jakarta MRT who rides MRT from Lebak Bulus Station. The researcher used quantitative method and used Simple random sampling to take the sample. To calculate data, the researcher did correlation test, linear regression analysis, hypothesis test, and determination coefficient. The result of this research showed that the service quality: reliable responsiveness, assurance, emphaty, tangibles significantly had strong connection towards society satisfaction. The questionnaire which contained 24 questions was valid and reliable because $r$ table value was bigger than $r$ count value and reliable value. The value of $r^{2}$ determination coefficient was $74.8 \%$. It means service quality (Independent) gave significant effect towards variable of society satisfaction. The researcher could conclude that there was positive effect given by service quality towards society satisfaction.
\end{abstract}

Keywords: Service Quality, Society Satisfaction, Mass Rapid Transit (MRT)

\begin{abstract}
Abstrak
MRT Jakarta dalam hal pelayanan di masa pandemic Covid-19 menerapkan protokol kesehatan yang ketat untuk mengurangi penyebaran covid-19. Kualitas pelayanan juga di tingkatkan demi kepentingan masyarakat pengguna MRT Jakarta. MRT Jakarta menerapkan protokol kesehatan BANGKIT (Bersih, Aman, Nyaman, Go Green, Kolaborasi, Inovasi, Tata Kelola) pada masa pandemic Covid-19. Penelitian ini bertujuan untuk mengetahui tingkat kualitas pelayanan terhadap kepuasan masyarakat pengguna MRT di stasiun Lebak Bulus khususnya pada masa pandemic Covid-19. Dalam penelitian ini penulis menggunakan metode kuantitatif dengan teknik pengambilan sample yaitu Simple random sampling, yaitu uji validitas dan reliabilitas, uji korelasi sederhana, analisis regresi linear, koefisien deteminasi, hipotetis. Hasil penelitian menunjukkan bahwa dimensi Service Quality berupa Reliability (keandalan), Responsiveness (daya tanggap), Assurance (jaminan), Emphaty (empati), Tangibles (bukti langsung) secara signifikan memiliki hubungan yang kuat dan positif terhadap kepuasan masyarakat. Dari 24 pernyataan kuesioner di nyatakan valid dan reliable di karenakan nilai $r$ tabel lebih besar dari nilai $r$-hitung dan juga nilai reliabilitas. Nilai $\mathrm{r}^{2}$ pada uji koefisien determinasi $74,8 \%$ hal ini berarti besar pengaruh variabel service quality (Independent) terhadap variabel kepuasan
\end{abstract}




\section{JURNAL ILMIAH ILMU ADMINISTRASI (JIIA) \\ Vol 10, No 2 (2020) HAL 55 - 69 \\ http://ejournal.unis.ac.id/index.php/JIIA}

ISSN: 2716-2621

masyarakat. Kesimpulan dari penelitian ini, bahwa kualitas pelayanan memiliki pengaruh yang sangat signifikan bagi kepuasan masyarakat.

\section{Keywords: Kualitas Pelayanan, Kepuasan Masyarakat, Mass Rapid Transit (MRT)}

\section{A. Pendahuluan}

DKI Jakarta sebagai Ibu Kota, selalu mengalami peningkatan jumlah penduduk (Putri et al., 2018). semakin banyaknya jumlah penduduk maka semakin tinggi keperluan akan pelayanan seperti kesehatan, transportasi, listrik, air, telepon, sanitasi, pendidikan dan pemukiman (Kharisma et al., 2017). Tingginya jumlah penduduk maka semakin meningkatnya kebutuhan penduduk akan transportasi. Transportasi merupakan unsur utama dalam sistem hidup dan kehidupan, sistem kemasyarakatan dan sistem pemerintahan (Aminah, 2007).

Salah satu strategi yang dilakukan pemerintah DKI Jakarta melakukan pembenahan sistem transportasi, dengan cara membangun moda transportasi massal berbasis rel yaitu Mass Rapid Transit (MRT) yang sangat di tunggu-tunggu oleh masyarakat untuk mengurangi kemacetan (Bintari \& Pandiangan, 2016). Mass Rapid Transit atau MRT merupakan moda transportasi massal berbasis rel listrik yang efektif, nyaman dan cepat (Satriani et al., 2015). Dari masalah kemacetan di Jakarta masyarakat mengharapkan MRT Jakarta yang di kelola oleh PT MRT Jakarta dan di kendalikan Pemerintah Pusat dan Pemerintah Daerah DKI Jakarta (MRT Jakarta- Jakarta Metro Mass Rapid Transit, n.d.).

MRT Jakarta mulai dioperasikan pada Minggu, 24 Maret 2019. MRT sebagai jasa layanan transportasi berkewajiban memberikan pelayanan terbaik kepada pengguna MRT. Saat ini Mass Rapid Transit (MRT) melayani rute Lebak Bulus sampai Bundaran HI. MRT Jakarta sendiri memberikan akses layanan transportasi publik yang aman dan terjangkau. Dengan demikian, adanya transportasi publik MRT Jakarta yang membentuk persepsi dan harapan masyarakat pengguna MRT Jakarta terhadap layanan MRT Jakarta guna memperbaiki dan meningkatkan kualitas layanan publik (Diniaty et al., 2019).

Di era pandemic Covid-19 ini MRT Jakarta menerapkan protokol kesehatan untuk mengurangi penyebaran Covid-19. Protokol BANGKIT (Bersih Aman Nyaman Go Green Kolaborasi Inovasi Tata Kelola) protokol ini mengatur teknis penggunaan MRT pada masa pandemic ini. Selama PSBB Transisi waktu operasional MRT Jakarta pada hari kerja di mulai pukul 05.00-21.00 dengan selang waktu 10 menit, 5 menit pada jam sibuk (07.00-09.00 \& 17.0019.00) sedangkan di akhir pekan dan hari libur pukul 06.00-20.00 di perpendek dari hari kerja. Masyarakat yang menggunakan MRT Jakarta diharapkan membawa 12 perlengkapan sesuai dengan aturan protokol kesehatan di MRT Jakarta, antara lain masker, kartu jelajah multi trip, MRT-J mobile apps, hand sanitizer, alat ibadah pribadi, botol minum pribadi, vitamin (jika diperlukan), tisu kering, tisu basah, disinfektan, alat makan pribadi. Masyarakat yang memasuki kawasan MRT Jakarta harus mengikuti peraturan pengecekan suhu maksimal 37,3 derajat celcius serta terdapat stiker marka peron yang harus di patuhi oleh masyarat. Maka dari itu aturan social distancing dapat berjalan (Firmansyah et al., 2020). 
JURNAL ILMIAH ILMU ADMINISTRASI (JIIA)

Vol 10, No 2 (2020) HAL 55 - 69

http://ejournal.unis.ac.id/index.php/JIIA

ISSN: 2716-2621

PT. MRT Jakarta menerapkan protokol kesehatan yang ketat untuk mengurangi risiko terkena Covid-19. Protokol kesehatan di terapkan di semua stasiun MRT Jakarta termasuk Stasiun Lebak Bulus. Di sediakan hand sanitizer di seluruh titik ramai penumpang di 13 stasiun. Pembersihan rutin fasilitas secara keseluruhan tiga kali sehari di stasiun, mesin tiket, mesin tapping hingga lift. Selanjutnya pembersihan intensif di setiap kereta ratangga baik interior dan eksterior menggunakan disinfektan, kesehatan dan kebersihan petugas dan menerapkan alat pelindungan diri, pemeriksaan suhu bagi penumpang di pintu masuk hingga pembatasan 62-67 orang perkereta (Mudassir, 2020).

\section{Gambar 1. Jumlah penumpang MRT Jakarta}

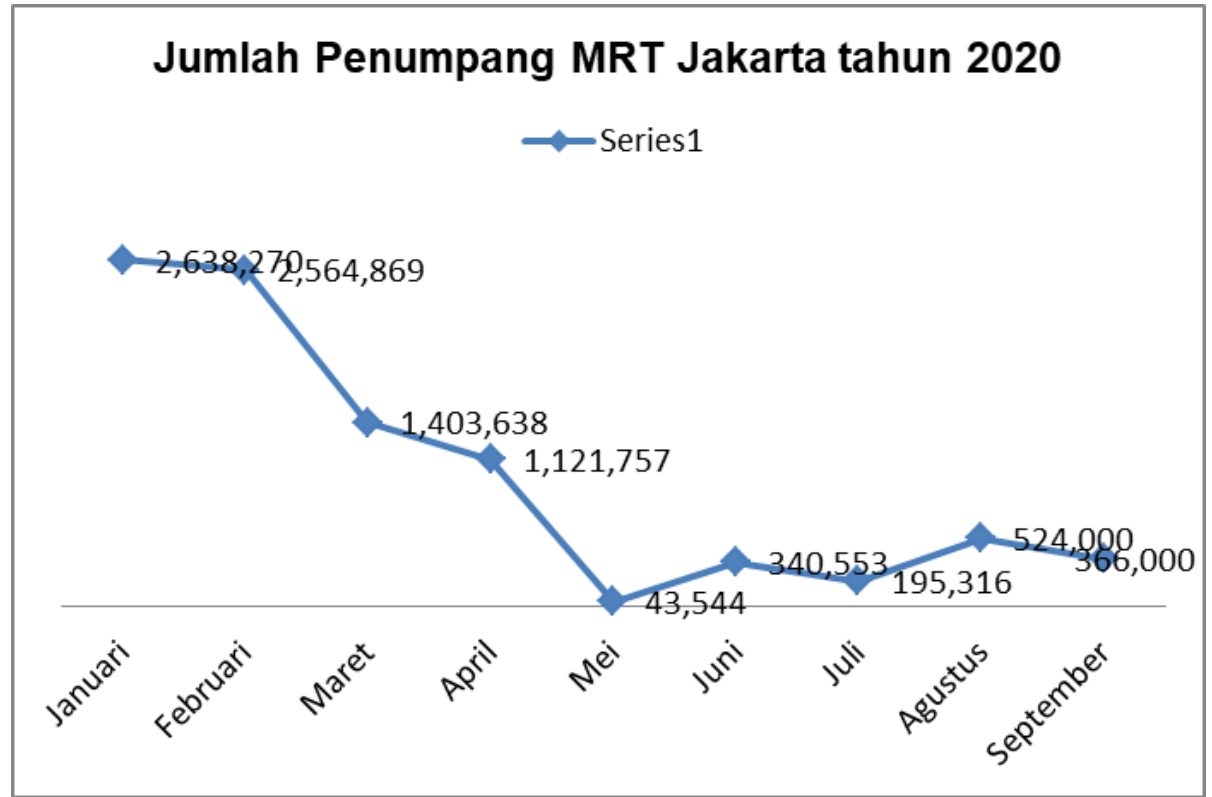

Sumber: PT. MRT Jakarta, 2020 (diolah)

Untuk mendapatkan pelayanan publik yang baik juga harus didukung oleh kualitas pelayanan publik (Service Quality). Pelayanan menjadi faktor yang sangat penting, meningkatkan kualitas pelayanan (Service Quality) sangat penting karena untuk meningkatkan kepuasan masyarakat terhadap jasa transportasi (Febriyanti et al., 2018). Kualitas berawal dari kebutuhan pelanggan dan diakhiri dengan pencapaian kualitas pelayanan yang baik. organisasi yang mampu dalam memberikan dan memenuhi harapan pelanggan menunjukan kualitas pelayanan di organisasi tersebut (Aditya, 2018). Kepuasan muncul karena adanya perbandingan harapan dengan apa yang telah diterima oleh pengguna layanan tersebut (Noersanti \& Prasetyo, 2020).

Kepuasan masyarakat sangat penting untuk mengevaluasi kualitas pelayanan dengan mengukur sejauh mana respon masyarakat terhadap penerimaan jasa layanan transportasi, dengan di adakannya kualitas layanan yang baik. Maka akan terciptanya kepuasan masyarakat. 


\section{JURNAL ILMIAH ILMU ADMINISTRASI (JIIA) \\ Vol 10, No 2 (2020) HAL 55 - 69 \\ http://ejournal.unis.ac.id/index.php/JIIA}

ISSN: 2716-2621

Antara kualitas pelayanan dan kepuasan masyarakat memiliki hubungan yang erat, karena adanya kepuasan masyarakat bisa mempengaruhi kualitas pelayanan dikarenakan tingkat kepuasan masyarakat dapet mempengaruhi dan meningkatkan harapan masyarakat terhadap suatu jasa atau layanan (Dewi et al., 2019).

Penelitian terdahulu yang di lakukan oleh (Ibrahim et al., 2019) dengan hasil penelitian menunjukan bahwa adanya perbedaan yang signifikan antara harapan dan persepsi penumpang kereta komuter di Kuala Lumpur. harapan penumpang secara konsisten lebih tinggi dibandingkan dengan kepuasan masyarakat. Malayan Railways Limited (KTMB) diharapkan bisa meningkatkan kualitas pelayanan mulai dari harga tiket, waktu kedatangan dan keberangkatan kereta secara tepat, serta loket tiket. Selanjutnya, penelitian terdahulu oleh (Lee \& Ng, 2018) dengan hasil penelitian Hasil penelitian ini menunjukan bahwa kualitas pelayanan memiliki hubungan yang sedang dan rendah terhadap pengaruh kepuasan pelanggan. Rendahnya pengaruh kualitas pelayanan terhadap kepuasan pelanggan dapat di benarkan karena tidak semua dimensi kualitas layanan dapat mengarah pada kepuasan pelanggan.

Sedangkan penelitian menurut (Chongsanguan et al., 2017) dengan hasil penelitian persepsi kualitas layanan secara signifikan mempengaruhi nilai persepsi penumpang. Kedua persepsi kualitas layanan dan nilai persepsi mempengaruhi pelanggan secara signifikan kepuasan dan semua ini secara signifikan mempengaruhi niat pembelian pelanggan.

Adapun tujuan dari penelitian ini yaitu mengetahui tingkat kualitas pelayanan terhadap kepuasan masyarakat di Mass Rapid Transit (MRT) di Stasiun Lebak Bulus. Berdasarkan uraian diatas, maka penelitian ini diharapkan memberikan manfaat yang dapat di ambil adalah memberikan Saran khususnya meningkatkan kualitas pelayanan serta persepsi kepuasan masyarakat terhadap pelayanan guna meningkatkan kualitas layanan yang baik.

Berdasarkan uraian diatas, rumusan masalah yang akan diteliti, yaitu bagaimana Pengaruh Service Quality terhadap kepuasan masyarakat Mass Rapid Transit (MRT) di Stasiun Lebak Bulus pada masa pandemic Covid-19 dan Bagaimana hubungan Service Quality terhadap kepuasan masyarakat Mass Rapid Transit (MRT) di Stasiun Lebak Bulus pada Masa Pandemic Covid-19.

\section{B. Tinjauan Pustaka (Literature Review)}

Kualitas jasa yang dinilai pelanggan menurut Zeithaml et al. dibagi dalam lima dimensi yaitu reliability (keandalan), responsiveness (cepat tanggap), assurance (jaminan), emphaty (empati), dan tangibles (bukti langsung) (Afthanorhan et al., 2019). Kualitas pelayanan merupakan faktor penting dalam mewujudkan kepuasan pelanggan (Mulatsih et al., 2018). Secara konsep, kualitas layanan merupakan persepsi konsumen tentang tingkat layanan tinggi atau rendah (Tanudjaya, 2014).

Sedangkan Menurut (Mugion et al., 2018) kualitas pelayanan bisa diartikan sesuatu yang melibatkan dua aspek, harapan dan persepsi. Dalam hal ini, kualitas pelayanan bisa 


\section{JURNAL ILMIAH ILMU ADMINISTRASI (JIIA) \\ Vol 10, No 2 (2020) HAL 55 - 69 \\ http://ejournal.unis.ac.id/index.php/JIIA \\ ISSN: 2716-2621}

diartikan sebagai kesenjangan antara harapan dan persepsi dalam proses pelayanan. Harapan dan kepuasan adalah dua hal yang tidak bisa terpisahkan dalam proses pelayanan dan harus dipertimbangkan oleh penyedia layanan.

Kualitas pelayanan merupakan kompetensi jasa layanan dalam melaksanakan pelayanan pada para konsumen (Molden Elrado H, Srikandi Kumadji, 2014).Kualitas layanan adalah penilaian secara keseluruhan oleh pelanggan terhadap kinerja layanan yang disediakan (Ibrahim et al., 2019).

Kualitas layanan harus di mulai dan diakhiri dengan persepsi pelanggan. Kualitas pelayanan yang baik tidak dilihat dari persepsi perusahaan atau jasa pelayanan tetapi dilihat dari persepsi pelanggan. Untuk mendapatkan pelayanan yang baik meningkatkan nilai layanan yang baik dan meningkatkan kualitas layanan produk (Suwarsito et al., 2020).

Dimensi Service Quality dalam (Tjiptono \& Chandra, 2005) menerangkan bahwa. Sehingga disederhanakan menjadi lima dimensi antara lain sebagai berikut :

1. Realiability (keandalan) yaitu kemampuan suatu jasa layanan memberikan pelayanan yang tepat tanpa membuat kesalahan apapun serta sesuai dengan waktu yang telah disepakati.

2. Responsiveness (daya tanggap) yaitu kesiapan dan kemampuan karyawan untuk membantu pelanggan dan merespon dan menginformasikan kepada pelanggan secara akurat dan cepat.

3. Assurance (jaminan) yaitu perilaku karyawan mampu menumbuhkan kepercayaan pelanggan terhadap jasa layanan dan suatu jasa layanan bisa menciptakan rasa aman bagi para pelanggannya. Jaminan berarti karyawan selalu bersikap sopan dan menguasai pengetahuan dan kesiaptanggapan untuk menangani setiap pertanyaan atau masalah pelanggan.

4. Emphaty (empati) yakni jasa layanan memahami masalah pelanggannya dan bertindak demi kepentingan pelanggan, serta memberikan pelayanan yang optimal kepada para pelanggan dan memiliki jam operasional yang nyaman.

5. Tangibles (bukti langsung) berkenaan dengan daya tarik fasilitas fisik, perlengkapan dan material yang digunakan oleh jasa layanan serta penampilan karyawan.

Dapat di simpulkan pengertian Service Quality adalah penilaian pelanggan terhadap suatu produk, jasa pelayanan untuk memenuhi harapan pelanggan. Persepsi kualitas pelayanan dapat di nilai pelanggan terhadap pelayanan yang di berikan oleh penyedia jasa. Kualitas merupakan sebuah takaran nilai yang harus dipenuhi oleh penyedia jasa yang harus dikerjakan dengan baik. nilai yang diberikan pelanggan merupakan faktor utama kualitas pelayanan. Pada dasarnya kualitas pelayanan upaya untuk memenuhi kepuasan dan kebutuhan pelanggan untuk mengimbangi harapan pelanggan.

Kata kepuasan atau satisfaction menurut Tjiptono dan Gregorius Candra berasal dari bahasa latin "satis" yang berarti cukup baik, memadai, dan "factio" yang berarti melakukan atau membuat. Kepuasan bisa di artikan sebagai "upaya pemenuhan sesuatu" atau "membuat 
JURNAL ILMIAH ILMU ADMINISTRASI (JIIA)

Vol 10, No 2 (2020) HAL 55 - 69

http://ejournal.unis.ac.id/index.php/JIIA

ISSN: 2716-2621

sesuatu memadai" (Tjiptono \& Chandra, 2005). Menurut Kotler dan Keller kepuasan atau satisfaction adalah perasaan atau kondisi yang muncul setelah membandingkan kinerja (hasil) produk yang telah menenuhi kinerja atau hasil yang di harapkan. Apabila kinerja berada di bawah harapan maka pelanggan puas sebaliknya jika kinerja melebihi harapan pelanggan maka pelanggan puas atas kinerja tersebut.(Kotler \& Keller, 2008).

Menurut Nursalam, Kepuasan adalah perasaan senang seseseorang yang berasal dari perbandingan antara kesenangan terhadap aktivitas dan suatu produk sesuai harapannya (Nursalam, 2010). Choi dan kim mengemukakan bahwa kepuasan pelanggan secara langsung dipengaruhi oleh kualitas interaksi yaitu kualitas interaksi antara pelanggan dan karyawan (Choi \& Kim, 2013). Kepuasan pelanggan tergantung pada kinerja layanan terhadap harapan pelanggan (Börjesson \& Rubensson, 2019).

\section{Metode}

Dalam penelitian ini metode yang di gunakan yaitu kuantitatif dimana penelitian di lakukan dengan cara survey dan menyebar kuesioner untuk mengetahui persepsi dari masyarakat pengguna layanan Mass Rapid Transit. Populasi dalam penelitian ini adalah pengguna jasa layanan Mass Rapid Transit (MRT). Teknik pengumpulan data yang digunakan dalam penelitian ini yaitu data primer dan data sekunder, data primer yaitu data yang di peroleh dari lapangan atau lokasi penelitian melalui pengisian kuesioner dan observasi. Sedangkan data sekunder adalah data yang di dapat dari sumber-sumber pustaka seperti buku, jurnal, Tesis Disertasi dan lain sebagainya (Sugiyono, 2018).

Metode sampling yang di gunakan yaitu simple random sampling dikarenakan pengambilan sample secara acak yang telah di tetapkan dari populasi yang telah di tetapkan. Sample yang di tentukan berjumlah 400 responden pengguna Mass Rapid Transit. Dari 400 responden tersebut di ambil sample untuk mengisi kuesioner yang di tentukan (Sugiyono, 2018). Teknik pengukuran dalam penelitian ini menggunakan skala likert dimana variabel yang diukur dijabarkan menjadi indicator variabel. Dalam menentukan indikator variabel maka perlu membuat operasional variabel, maka dapat dilihat dari tabel berikut.

Tabel 1. Operasional Variabel

\begin{tabular}{|l|l|l|l|l|}
\hline \multicolumn{1}{|c|}{ Variabel } & \multicolumn{1}{|c|}{ Indikator } & \multicolumn{1}{|c|}{ Dimensi } & \multicolumn{1}{c|}{ Sumber } \\
\hline $\begin{array}{l}\text { Kualitas Layanan } \\
\text { Menurut Tjiptono } \\
\text { \& Chandra (2005) }\end{array}$ & $\begin{array}{l}\text { Reliability } \\
\text { (Keandalan) }\end{array}$ & $\begin{array}{l}\text { memberikan layanan yang } \\
\text { akurat }\end{array}$ & $\begin{array}{l}\text { (Tjiptono } \\
\text { Chandra, 2005) }\end{array}$ \\
\hline
\end{tabular}


JURNAL ILMIAH ILMU ADMINISTRASI (JIIA)

Vol 10, No 2 (2020) HAL 55 - 69

http://ejournal.unis.ac.id/index.php/JIIA

ISSN: 2716-2621

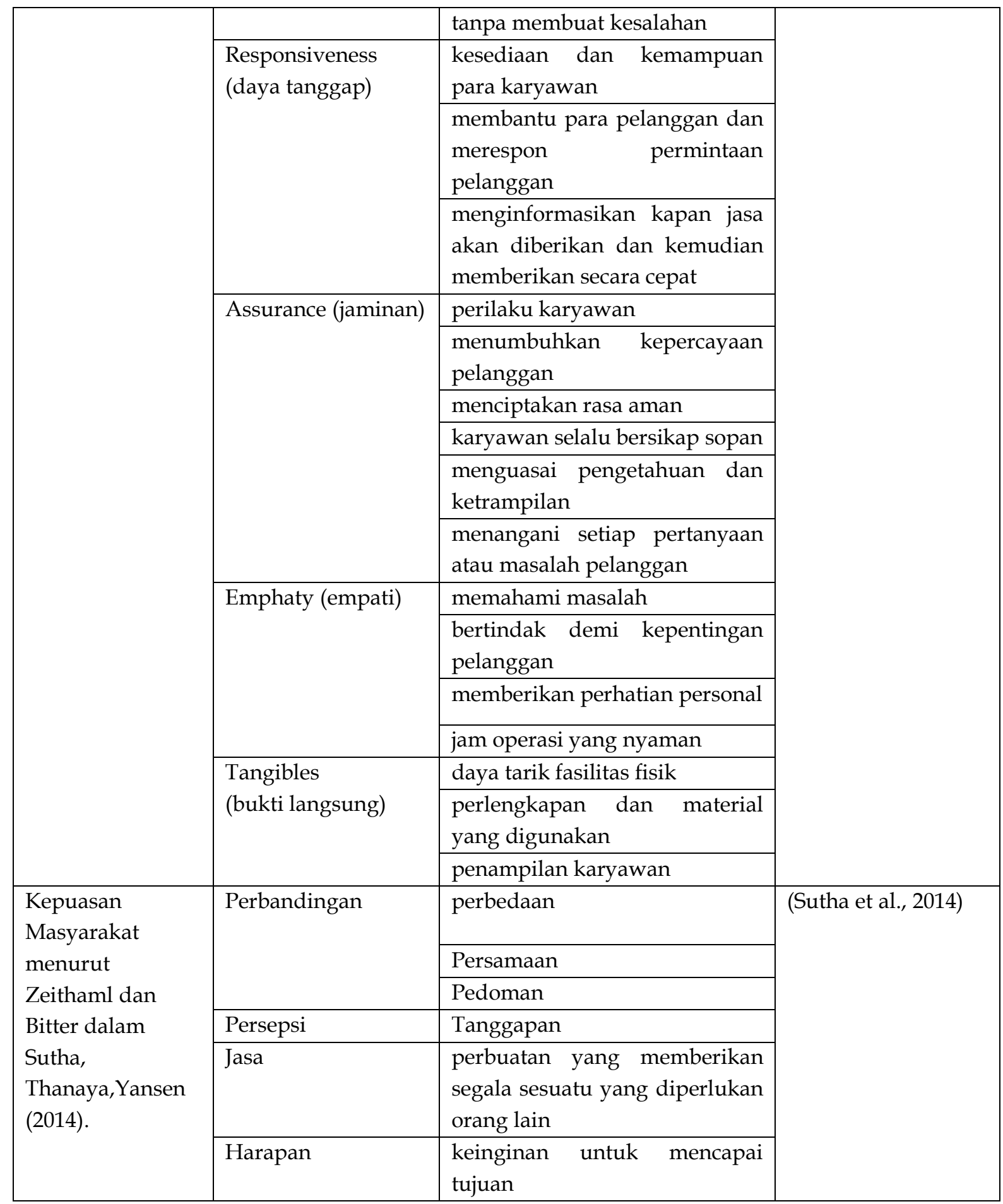

Sumber : diolah penulis tahun 2020 
JURNAL ILMIAH ILMU ADMINISTRASI (JIIA)

Vol 10, No 2 (2020) HAL 55 - 69

http://ejournal.unis.ac.id/index.php/JIIA

ISSN: 2716-2621

\section{Temuan Hasil Penelitian (Research Finding)}

Berdasarkan hasil uji validitas yang dilakukan dengan 400 responden merupakan pengguna MRT Jakarta di stasiun Lebak Bulus. Berdasarkan hasil perhitungan Spss for windows versi 24 pada penelitian ini dinyatakan valid. hal ini dapat dilihat dari tabel berikut :

Tabel 2. Hasil uji validitas dan reliabilitas

\begin{tabular}{|c|c|c|c|}
\hline Pernyataan & r-hitung & r-tabel & Keterangan \\
\hline \multicolumn{4}{|c|}{ Service Quality $(X)$} \\
\hline 1 & 0.528 & 0.098 & Valid \\
\hline 2 & 0.675 & 0.098 & Valid \\
\hline 3 & 0.741 & 0.098 & Valid \\
\hline 4 & 0.765 & 0.098 & Valid \\
\hline 5 & 0.780 & 0.098 & Valid \\
\hline 6 & 0.682 & 0.098 & Valid \\
\hline 7 & 0.769 & 0.098 & Valid \\
\hline 8 & 0.768 & 0.098 & Valid \\
\hline 9 & 0.746 & 0.098 & Valid \\
\hline 10 & 0.713 & 0.098 & Valid \\
\hline 11 & 0.754 & 0.098 & Valid \\
\hline 12 & 0.784 & 0.098 & Valid \\
\hline 13 & 0.759 & 0.098 & Valid \\
\hline 14 & 0.756 & 0.098 & Valid \\
\hline 15 & 0.709 & 0.098 & Valid \\
\hline 16 & 0.666 & 0.098 & Valid \\
\hline 17 & 0.775 & 0.098 & Valid \\
\hline 18 & 0.656 & 0.098 & Valid \\
\hline \multicolumn{4}{|c|}{ Kepuasan Masyarakat (Y) } \\
\hline 1 & 0.677 & 0.098 & Valid \\
\hline 2 & 0.723 & 0.098 & Valid \\
\hline 3 & 0.768 & 0.098 & Valid \\
\hline 4 & 0.822 & 0.098 & Valid \\
\hline 5 & 0.846 & 0.098 & Valid \\
\hline 6 & 0.792 & 0.098 & Valid \\
\hline
\end{tabular}

Sumber: hasil olah data SPSS 24

Dari hasil perbandingan uji validitas variabel service quality $(\mathrm{x})$ dan varibel kepuasan masyarakat (y) antara r-hitung lebih besar dari r-tabel 0.098. Untuk menentukan valid atau tidaknya suatu penyataan ada dua sisi pada tingkat signifikansi 5\% dengan tingkat kepercayaan 95\%. Derajat kebebasan $(\mathrm{df})=\mathrm{n}-2=400-2=398$. Hal ini di dapat $\mathrm{r}$-tabel dengan df 
JURNAL ILMIAH ILMU ADMINISTRASI (JIIA)

Vol 10, No 2 (2020) HAL 55 - 69

http://ejournal.unis.ac.id/index.php/JIIA

ISSN: 2716-2621

398 pada taraf signifikan $5 \%$ yaitu 0.098. dari tabel penelitian di atas dapat dikatakan dan bisa dilanjutkan ketahap penelitian.

Berdasarkan uji reliabilitas cronbach alpha dapat di lihat nilai dari 24 item pernyataan kuesioner tersebut reliable di karenakan nilai cronbach alpha lebih dari nilai r-tabel 0.098 dari 24 pertanyaan kuesioner.

\section{Koefisien korelasi sederhana}

\begin{tabular}{|c|c|c|c|}
\hline & & $\begin{array}{l}\text { Service } \\
\text { Quality }\end{array}$ & $\begin{array}{l}\text { Kepuasan } \\
\text { Masyarakat }\end{array}$ \\
\hline \multirow[t]{3}{*}{ Service Quality } & $\begin{array}{l}\text { Pearson } \\
\text { Correlation }\end{array}$ & 1 & .865 \\
\hline & Sig. (2-tailed) & & .000 \\
\hline & $\mathrm{N}$ & 400 & 400 \\
\hline \multirow[t]{3}{*}{$\begin{array}{l}\text { Kepuasan } \\
\text { Masyarakat }\end{array}$} & $\begin{array}{l}\text { Pearson } \\
\text { Correlation }\end{array}$ & .865 & 1 \\
\hline & Sig. (2-tailed) & .000 & \\
\hline & $\mathrm{N}$ & 400 & 400 \\
\hline
\end{tabular}

Sumber: hasil olah data SPSS 24

dari hasil output koefisien korelasi sederhana (r) pada tabel 3 dapat di lihat korelasi antara variabel $\mathrm{X}$ dan variabel $\mathrm{Y}$ adalah 0.865. r-hitung 0.865 lebih besar dari pada r-tabel 0.098, maka hal ini menunjukan hasil yang valid dengan koefisiensi interprestasi hubungan positif sangat kuat berarti berdasarkan tabel di atas.

Regresi Linear Sederhana

Tabel 4. Hasil uji regresi linear sederhana

Coefficients $^{a}$

\begin{tabular}{lll|l|l|l|l}
\multicolumn{1}{c}{} & \multicolumn{2}{l}{$\begin{array}{l}\text { Unstandardized Coefficients } \\
\text { Model }\end{array}$} & $\begin{array}{l}\text { Standardized } \\
\text { Coefficients } \\
\text { Beta }\end{array}$ & T & Sig. \\
\hline 1 & B Constant) & 2.084 & .677 & & 3.080 & .002 \\
\cline { 2 - 8 } & Service Quality & .305 & .009 & .865 & 34.366 & .000 \\
\hline
\end{tabular}

a. Dependent Variable: Kepuasan Masyarakat

Sumber: hasil olah data SPSS 24

Berdasarkan tabel hasil uji regresi linear sederhana di atas bahwa nilai a kostanta adalah 2.084 hal ini berarti nilai konsisten dari variabel kepuasan pelanggan adalah 2.084. selanjutnya koefiensi regresi service quality $(\mathrm{X})$ sebesar 0.305 artinya bernilai positif. Apabila ada peningkatan pada variabel service quality maka secara langsung kepuasan masyarakat pengguna MRT Jakarta di Stasiun Lebak Bulus meningkat sebesar 0.305. 
JURNAL ILMIAH ILMU ADMINISTRASI (JIIA)

Vol 10, No 2 (2020) HAL 55 - 69

http://ejournal.unis.ac.id/index.php/JIIA

ISSN: 2716-2621

\section{Koefisien determinasi}

Tabel 5. hasil uji koefisien determinasi

\begin{tabular}{ll|l|l|l|l}
\multicolumn{2}{c}{ Model Summary } & \multicolumn{2}{l}{ Adjusted } & $R$ & $\begin{array}{l}\text { Std. Error of the } \\
\text { Estimate }\end{array}$ \\
Model & $\mathrm{R}$ & $\mathrm{R}$ Square & Square & \\
\hline 1 & $.865^{\mathrm{a}}$ & .748 & .747 & 1.732 \\
\hline
\end{tabular}

a. Predictors: (Constant), Service Quality

Sumber: hasil olah data SPSS 24

Tabel 5 menunjukan bahwa nilai $\mathrm{r}^{2}$ sebesar 74,8\% dapat di simpulkan bahwa besar pengaruh variabel service quality (Independent) terhadap variabel kepuasan masyarakat (depentdent) yaitu sebesar 74,8\% dan sisanya 25,2\% di pengaruhi oleh variabel lain.

\section{Hipotesis}

Hipotesis pada penelitian ini di lakukan pada tingkat signifikansi 5\%. Untuk menguji hipotesis dapat membandingkan t-hitung dengan t-tabel yaitu 34,366 > 1966. Berdasarkan tabel 6 dapat disimpulkan hasil hipotesis t-hitung sebesar 34.366 sedangkan tabel t-tabel dengan derajat kebebasan (df) 398 sebesar 1966. Maka t-hitung lebih besar dari t-tabel artinya Ho di tolak dan Ha di terima yang berarti adanya pengaruh yang signifikan antara service quality terhadap kepuasan masyarakat pengguna MRT Jakarta di Stasiun Lebak Bulus.

Tabel 6. Hasil uji t

\section{Coefficients $^{a}$}

\begin{tabular}{|c|c|c|c|c|c|c|}
\hline \multirow{2}{*}{\multicolumn{2}{|c|}{ Model }} & \multicolumn{2}{|c|}{ Unstandardized Coefficients } & \multirow{2}{*}{$\begin{array}{l}\text { Standardized } \\
\text { Coefficients } \\
\text { Beta }\end{array}$} & \multirow[b]{2}{*}{$\mathrm{T}$} & \multirow[b]{2}{*}{ Sig. } \\
\hline & & $\mathrm{B}$ & Std. Error & & & \\
\hline \multirow[t]{2}{*}{1} & (Constant) & 2.084 & .677 & & 3.080 & .002 \\
\hline & Service Quality & .305 & .009 & .865 & 34.366 & .000 \\
\hline
\end{tabular}

a. Dependent Variable: Kepuasan Masyarakat

Sumber: hasil olah data SPSS 24

\section{E. Diskusi}

Penelitian ini di lakukan dengan menyebar kuesioner melalui Social media Twitter. Data responden penelitian ini sebanyak 400 orang pengguna MRT Jakarta di Stasiun Lebak Bulus dari hasil perhitungan rumus slovin. Penelitian ini menggunakan analisis SPSS for windows versi 24 . 
JURNAL ILMIAH ILMU ADMINISTRASI (JIIA)

Vol 10, No 2 (2020) HAL 55 - 69

http://ejournal.unis.ac.id/index.php/JIIA

ISSN: 2716-2621

Gambar 2. Data Jenis Kelamin

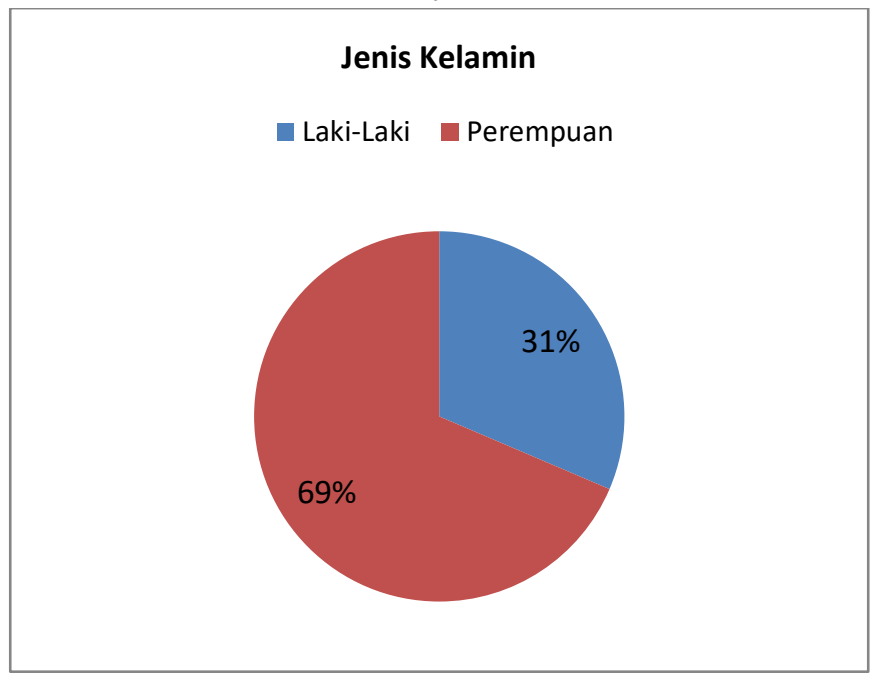

Sumber: diolah Microsoft excel

Karakteristik responden berdasarkan jenis kelamin, data berdasarkan jenis kelamin responden laki-laki berjumlah 126 orang (31\%) sedangkan perempuan berjumlah 275 orang (69\%). hal ini membuktikan bahwa rata-rata penumpang MRT Jakarta khususnya Stasiun Lebak perempuan lebih banyak di banding dengan penumpang laki-laki.

\section{Gambar 3. Data Usia Responden}

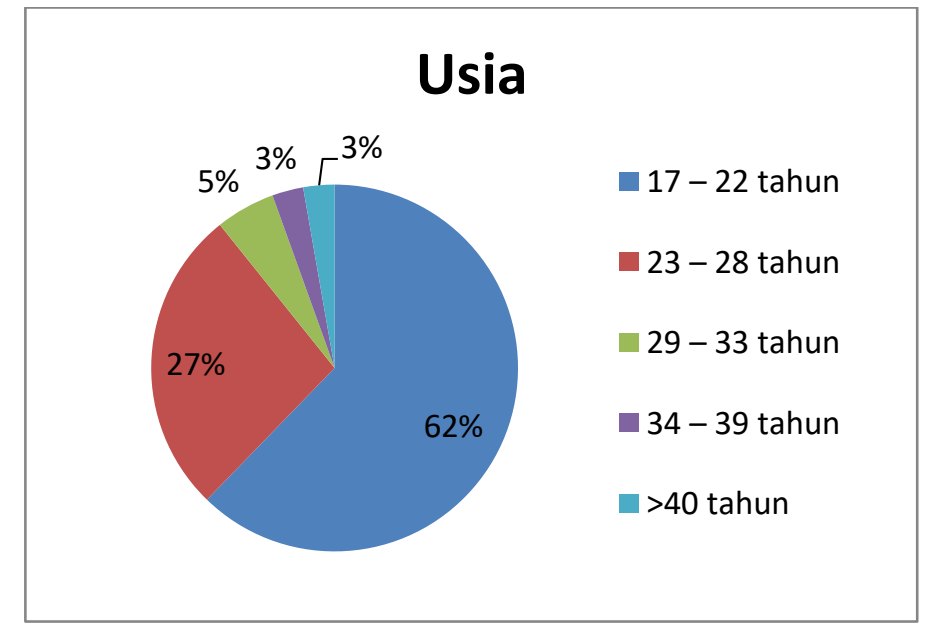

Sumber: diolah Microsoft excel

Karakteristik responden berdasarkan usia dengan kategori usia 17-22 tahun berjumlah sebanyak 249 orang (62\%), pengguna MRT berusia 23-28 tahun berjumlah 108 orang (27\%), 
pengguna MRT berusia 29-33 tahun berjumlah 21 orang (5\%), pengguna MRT berusia 34-39 tahun berjumlah 11 (3\%) dan pengguna MRT berusia $>40$ tahun berjumlah 11 orang ( $3 \%$ ).

Gambar 4. Data Pendidikan Responden

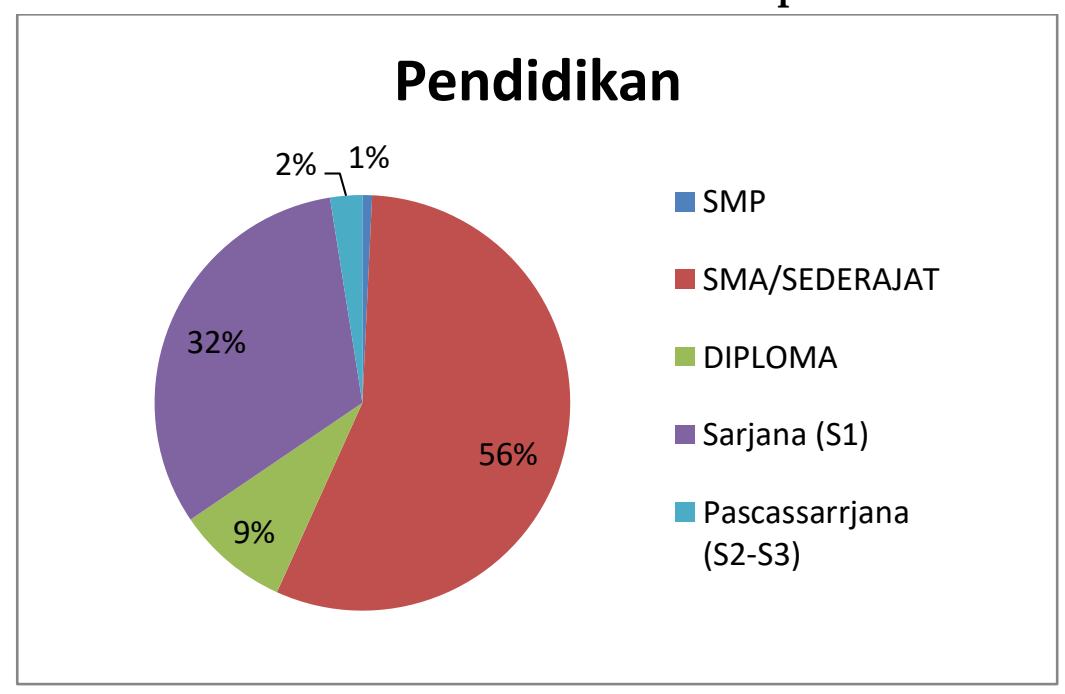

Sumber: diolah Microsoft excel

Karakteristik berdasarkan tingkat pendidikan, data menunjukan responden dengan pendidikan terakhir SMP terdapat 3 orang $(2 \%)$, pendidikan terakhir SMA/Sederajat terdapat 224 orang $(56 \%)$, pendidikan terakhir Diploma terdapat 35 orang $(9 \%)$, pendidikan terakhir Sarjana (S1) berjumlah 128 orang (32\%) sedangkan untuk pendidikan terakhir Pascasarjana (S2S3) berjumlah 10 orang (1\%). Dari jumlah pendidikan terakhir diatas dapat di simpulkan bahwa rata-rata pengguina MRT Jakarta di Stasiun Lebak Bulus Berpendidikan SMA/Sederajat.

Berdasarkan hasil penelitian di atas antara variabel service quality mempengaruhi variabel kepuasan masyarakat. Artinya semakin bagus tingkat kualitas suatu layanan maka semakin tinggi tingkat kepuasan masyarakat pengguna jasa layanan tersebut. Dalam hal ini pengguna MRT Jakarta di stasiun lebak bulus merasakan adanya kepuasan dari service quality yang ada di MRT Jakarta khususnya Stasiun Lebak Bulus baik pelayanan saat pandemic Covid19 diterapkan sangat ketat demi keamanan dan kenyamanan penumpang. Hal ini sesuai dengan penelitian yang dilakukan oleh (Egi; \& Budhi, 2019) bahwa service quality (kualitas layanan) yang diberikan oleh jasa layanan akan mempengaruhi pada kepuasan masyarakat.

Berdasarkan hasil observasi, Kualitas pelayanan pada saat pandemic Covid-19 memenuhi standar protokol kesehatan yang berlaku selama pandemic Covid-19 artinya masyarakat pengguna MRT Jakarta di Stasiun Lebak Bulus merasakan kualitas layanan yang baik selama pandemic Covid-19 ini.

Hal ini dapat di lihat dari hasil uji regresi linear sederhana bahwa terdapat pengaruh antara variabel service quality terhadap kepuasan masyarakat dengan nilai signifikansi 0.002 kurang dari 0.005 artinya berpengaruh. Hasil uji determinasi $\left(\mathrm{r}^{2}\right)$ menunjukan nilai Adjust $\mathrm{R}$ 
JURNAL ILMIAH ILMU ADMINISTRASI (JIIA)

Vol 10, No 2 (2020) HAL 55 - 69

http://ejournal.unis.ac.id/index.php/JIIA

ISSN: 2716-2621

Square sebesar 0.747 atau 74,7\% yang berarti besar pengaruh service quality terhadap kepuasan masyarakat dan sisanya di pengaruhi oleh variabel lain yang tidak di teliti. Serta di dapatkan pula nilai koefisien korelasi sebesaar 0,865* yang menunjukan bahwa kedua variabel memiliki korelasi yang sangat kuat dikarenakan nilainya berada di atas 0,5 signifikansi. Dalam hal ini,semakin tinggi Service Quality $(X)$ maka semakin tinggi pula Kepuasan Masyarakat atas kualitas pelayanan yang di berikan.

Berdasarkan hasil perhitungan di atas dapat di lihat jika terdapat pengaruh yang signifikan antara service quality (reliability, responsiveness, assurance, emphaty, tangibles) terhadap kepuasan masyrakat di MRT Jakarta Stasiun Lebak bulus. Hal ini berarti tingkat kualitas layanan di Stasiun Lebak Bulus sangat baik sehingga memenuhi harapan pelanggan terhadap kepuasan masyarakat sesuai dengan penelitian (Krisdayanto et al., 2018) berarti kualitas layanan adalah sejauh mana perbedaan antara harapan dan realita terhadap kepuasan pelanggan yang mereka terima.

\section{F. Kesimpulan}

Dari hasil analisis, dapat di simpulkan bahwa service quality memiliki pengaruh yang signifikan terhadap kepuasan masyarakat. Apabila kualitas pelayanannya baik maka harapan masyarakat terhadap pelayanan tersebut tinggi. MRT Jakarta menerapkan pelayanan selama pandemic Covid-19 secara optimal dan prosedur yang ketat.

Dari hasil analisis uji $\mathrm{t}$ hipotesis $\mathrm{t}$ hitung $34.366>\mathrm{t}$ tabel 1966 dapat di simpulkan ada pengaruh antara variabel service quality $(X)$ terhadap kepuasan masyarakat secara signifikan. Adapun hasil analisis dari uji regresi linear sederhana di dapat a kostanta 2.084 artinya jika service quality nilainya 0 maka kepuasan masyarakat $(Y)$ sebesar 2.084. Sedangkan koefisien regresi $X$ sebesar 0.305 bernilai positif. Setiap penambahan 1 nilai service quality maka nilai kepuasan masyarakat mengalami peningkatan 0.305 .

Pelayanan pada saat pandemic covid-19 berdasarkan 5 indikator penelitian realiability (keandalan), responsiveness (daya tanggap), assurance (jaminan), emphaty (empati) dan tangibles (bukti langsung) di Stasiun Lebak Bulus sangat ketat mulai dari waktu kedatangan kereta, keandalan dan daya tanggap petugas serta protokol kesehatan yang di terapkan sangat di perhatikan untuk mengurangi tingkat penyebaran covid-19 di jasa transportasi umum.

\section{Referensi}

Aditya, T. (2018). Analisis Kualitas Pelayanan Posyandu Camar Kelurahan Poris Plawad Utara Kecamatan Cipondoh Kota Tangerang. Journal Of Government And Civil Society, 1(2), 203. Https:/ / Doi.Org/10.31000/Jgcs.V1i2.445

Afthanorhan, A., Awang, Z., Rashid, N., Foziah, H., \& Ghazali, P. L. (2019). Assessing The Effects Of Service Quality On Customer Satisfaction. Management Science Letters, 9(1), 1324. Https://Doi.Org/10.5267/J.Msl.2018.11.004

Aminah, S. (2018). Transportasi Publik Dan Aksesibilitas Masyarakat Perkotaan. Masyarakat, Kebudayaan Dan Politik. Http://Jurnal.Ubl.Ac.Id/Index.Php/Jts/Article/View/1135 


\section{JURNAL ILMIAH ILMU ADMINISTRASI (JIIA) \\ Vol 10, No 2 (2020) HAL 55 - 69 \\ http://ejournal.unis.ac.id/index.php/JIIA}

ISSN: 2716-2621

Bintari, A., \& Pandiangan, L. H. S. (2016). Formulasi Kebijakan Pemerintah Tentang Pembentukan Badan Usaha Milik Daerah (Bumd) Perseroan Terbatas (Pt) Mass Rapid Transit (Mrt) Jakarta Di Provinsi Dki Jakarta. Cosmogov. Https:/ / Doi.Org/10.24198/Cosmogov.V2i2.10006

Börjesson, M., \& Rubensson, I. (2019). Satisfaction With Crowding And Other Attributes In Public Transport. Transport Policy, 79(May), 213-222. Https:/ / Doi.Org/10.1016/J.Tranpol.2019.05.010

Choi, B. J., \& Kim, H. S. (2013). The Impact Of Outcome Quality, Interaction Quality, And PeerTo-Peer Quality On Customer Satisfaction With A Hospital Service. Managing Service Quality, 23(3), 188-204. Https://Doi.Org/10.1108/09604521311312228

Chongsanguan, P., Trimetsoontorn, J., \& Fongsuwan, W. (2017). Examining The Relationships Between Service Quality, Perceived Value, Customer Satisfaction And Purchase Intentions: A Marketing Study Of Bangkok's Metropolitan Rapid Transit System, Thailand. Journal For Global Business Advancement, 10(1), 3-25. Https://Doi.Org/10.1504/Jgba.2017.081532

Dewi, K. L. L., Yulianthini, N. N., \& Ni Luh Wayan Telagawathi. (2019). Pengaruh Dimensi Kualitas Pelayanan Terhadap Kepuasan Pelanggan Pengguna Bpjs Kesehatan Di Kota Singaraja. Bisma: Jurnal Manajemen, 5(2), 82-92.

Diniaty, Avenia A., Triana, E., \& Miro, F. (2019). Kajian Persepsi Konsumen Terhadap Kualitas Pelayanan Transportasi Online (Grab Car) Di Kota Padang Dengan Metode Servqual. Abstract Of Undergraduate Research, Faculty Of Civil And Planning Engineering, Bung Hatta University, 2(3). Http:/ /Www.Ejurnal.Bunghatta.Ac.Id/?Journal=Jftsp\&Page=Article\&Op=View\&Path\%5 $\mathrm{b} \% 5 \mathrm{~d}=15765$

Egi;, R., \& Budhi, H. (2019). Loyalty Analysis Of Mass Transportation Facilities Customers Based On Service Quality And User Satisfaction: A Case Study Of Inter-City Train Customers In Indonesia. Eurasia: Economics \& Business, 7(July), 68-74.

Febriyanti, D. A. P., Mitariani, N. W. E., \& Imbayani, I. G. A. (2018). Pengaruh Kualitas Pelayanan Melalui Kepuasan Nasabah Terhadap Loyalitas Nasabah Pada Pt Bpr Saraswati Ekabumi. Juima: Jurnal Ilmu Manajemen, 8(1), 82-92.

Firmansyah, M. J., Arjanto, D., \& Rengganis, M. T. (2020). Mulai Besok Mrt Jakarta Terapkan Protokol Bangkit, Apa Saja? Https://Www.Jakartamrt.Co.Id/2020/06/07/Mulai-Besok-MrtJakarta-Terapkan-Protokol-Bangkit-Apa-Saja/

Ibrahim, Borhan, Zakaria, \& Zainal. (2019). Effectiveness Of Commuter Rail Service Toward Passenger's Satisfaction: A Case Study From Kuala Lumpur, Malaysia. International Journal Of Engineering And Technology, 8(1.2), 50-55. Https://Doi.Org/10.14419/Ijet.V8i1.2.24871

Kharisma, A., Santosa, E., \& Astuti, P. (2017). Persepsi Dan Partisipasi Masyarakat Dalam Pembangunan Infrastruktur (Studi Kasus Pembangunan Mrt Rute Koridor Selatan-Utara, Tahap 1, Lebak Bulus Jakarta Selatan. Journal Of Politic And Government, 6(04), 391-400.

Kotler, P., \& Keller, K. L. (2008). Philip_Kotler_Manajemen_Pemasaran_Edisi.Pdf (P. 19). Http:/ / Docplayer.Info/31435130-Bab-Iii-Landasan-Teori-Membeli-Untuk-MewujudkanKepuasan-Konsumen-Maka-Perusahaan-Harus.Html

Krisdayanto, I., Haryono, A. T., Pt, E. G., Analisis, H., Pelayanan, A. K., Fasilitas, L., \& Putra, Net B. (2018). Analisis Pengaruh Harga, Kualitas Pelayanan, Fasilitas, Dan Lokasi Terhadap Kepuasan Konsumen Di I Cafe Lina Putra Net Bandungan. Journal Of Management, 4(4). 


\section{JURNAL ILMIAH ILMU ADMINISTRASI (JIIA) \\ Vol 10, No 2 (2020) HAL 55 - 69 \\ http://ejournal.unis.ac.id/index.php/JIIA}

ISSN: 2716-2621

Lee, C., \& Ng, B. A. (2018). The Influence Of Service Quality And Service Recovery On Customer Satisfactions: A Case Study Of Mrt Users In Klang Valley. 9(December), 84-100.

Molden Elrado H, Srikandi Kumadji, E. Y. (2014). Pengaruh Kualitas Pelayanan Terhadap Kepuasan, Kepercayaan Dan Loyalitas (Survei Pada Pelanggan Yang Menginap Di Jambuluwuk Batu Resort Kota Batu). Jurnal Administrasi Bisnis S1 Universitas Brawijaya.

Mrt Jakarta- Jakarta Metro Mass Rapid Transit. (N.D.). Https://Www.Jakartamrt.Co.Id

Mudassir, R. (2020). Cara Mrt Jakarta Kurangi Risiko Penularan Virus Corona I Jakarta Bisnis.Com. Https://Jakarta.Bisnis.Com/Read/20200701/77/1260265/Cara-Mrt-Jakarta-KurangiRisiko-Penularan-Virus-Corona

Mugion, R. G., Toni, M., Raharjo, H., Di Pietro, L., \& Sebathu, S. P. (2018). Does The Service Quality Of Urban Public Transport Enhance Sustainable Mobility? Journal Of Cleaner Production, 174, 1566-1587. Https://Doi.Org/10.1016/J.Jclepro.2017.11.052

Mulatsih, R., Wahyudi, E., \& Sumantri, A. S. (2018). Manajemen Kualitas Pelayanan Transportasi Laut Dalam Meningkatkan Kepuasan Pelanggan Pada Jasa Bongkar Muat. Jurnal Organisasi Dan Manajemen, 14(2), 151-160. Https:/ / Doi.Org/10.33830/Jom.V14i2.160.2018

Noersanti, L., \& Prasetyo, T. A. (2020). Influence Service Quality, Brand Image, Location To Customer Satisfaction And Customer Loyalty (Case Study On Motorcycle Repair Shop Sahabat Motor-Cibinong Customer). Https://Doi.Org/10.2991/Aebmr.K.200331.033

Nursalam. (2010). Pendekatan Praktis Metodologi Riset Keperawatan. Cv Indomedika.

Putri, V. D., Komarudin, K., \& Destyanto, A. R. (2018). The Determination Of Mrt (Mass Rapid Transit) Jakarta Train Specification To Reach Headway Target By Using Promodel. Proceedings - 3rd International Conference On Computational Intelligence And Applications, Iccia 2018. Https:/ / Doi.Org/10.1109/Iccia.2018.00011

Satriani, A. M., Indarto, E., \& Nugroho, S. (2015). Stasiun Mass Rapid Transit (Mrt) Blok M Jakarta Dengan Konsep Hemat Energi. 10.

Sugiyono. (2018). Metode Penelitian Kuantitatif, Kualitatif Dan RED (27th Ed.). Alfabeta.

Suwarsito, S., Ghozali, S., Setianingrum, H. W., \& Alawiyah, S. (2020). Quality Of Service, Satisfaction And The Effect Towards Customer Loyalty. Jurnal Manajemen Bisnis, 7(1), 3239. Https://Doi.Org/10.33096/Jmb.V7i1.419

Tanudjaya, P. K. (2014). Pengaruh Kualitas Pelayanan Klinik Gigi Terhadap Kepuasan Dan Kepercayaan Pasien Sehingga Meningkatkan Keinginan Untuk Berobat Kembali. Jurnal Manajemen Dan Pemasaran Jasa, 7(1), 39. Https://Doi.Org/10.25105/Jmpj.V7i1.520

Tjiptono, F., \& Chandra, G. (2005). Service, Quality Dan Satisfaction (4th Ed.). Penerbit Andi. 